\title{
Slovak Republic's accession to the European Union
}

\section{Introductory remarks}

The aim of this article is to present the specificity of the accession process of the Slovak Republic to the European Union in comparison to other countries of Central Europe. The author attempted to find answers to the following three questions: What were the successive stages of Slovakian accession to EU; what were the reasons for negotiating with Slovakia later than with the other countiries of the same region; what issues were the most difficult during the course of the negotiation proces?

The article is based on the assumption that the politics of Vladimir Mečiar, in particular human rights breaches, negatively inluenced the process of Slovakia's accession to the European Union. Another hypothesis is that in comparison to other countries of Central Europe, Slovak political parties reached a national consensus concerning accession to the European Union.

In order to provide answers to the research questions and verify the hypothesis, the author used a numer of different research methods specific to the political sciences: historical analysis, decision - making analysis, institutional and legal analysis and system analysis.

\section{Establishing cooperation}

The Slovak Republic is a political descentant of Czehoslovakia, which established diplomatic ties with the European Community (EC) in the late 1980s. This was made possible by signing a common declaration between the European Economic Community (EEC) and the Council for Mutual Economic Assistance (CMEA) in Luxemburg on the $25^{\text {th }}$ of June 1988. It allowed the conclusion of bilateral trade agreements between selected countries of EEC and EMEA. In the case of Czechoslovakia, such an agreement was made on the $7^{\text {th }}$ May 1990 (Wojnicki, 2006, p.146). The process of systemic transformation facility in the countries of Central Europe started atthe end of the 1980s. Within the frames of foreign policy, the newly formed governments in these countries declared a willingness to join European structures. On $16^{\text {th }}$ December 1991, the EC made an agreement (the contract of association, 1991) with Czechoslovakia, Poland and Hungary (Ruzicka, 2009, p. 88). These countries received financial assistance under the plan of Poland and Hungary: Assistance for Restructuring their Economies (PHARE), which was originally intended to suport the reform process in Poland and Hungary. In September 1990 the plan was expanded to the Czech and Slovak Federative Republic. Another factor regarding the accession process to the European Communities was the initiation of cooperation within the Visegrád Group, The 
Central European Free Trade Agreement (CEFTA) and the Central European Initiative (CEI). On the $1^{\text {st January }} 1993$ two independent countries were founded: the Czech and Slovak Republics (Żarna, 2017, p. 59).

A significant moment for the Central European countries was a meeting of the European Council in Copenhagen on the $22^{\text {nd }}-23^{\text {rd }}$ June 1993. At that time, the criteria for entering the European Union were laid down. The requirements included: democratisation; respect of human rights, protection of national minorities and ethnic gropus, functioning of the market economy, achieving the objectives of political, economic and monetary union, the capacity of local administration to accept the Community's law (European Council, 1993, pp. 225-236).

In the case of Slovakia, a serious issue was the government's position regarding individuals belonging to the Roma and Hungarian community. On the $31^{\text {st }}$ of August 1993, the representatives of Hungarian parties sent a letter to European Council regarding the fact, that Slovak's government did not meet the requirements concerning the respect for national minorities and ethnical groups, which they agreed to follow when accessing the Union. The situation was enhanced by Vladimir Mečiar, who on the $3^{\text {rd }}$ September 1993 in Spiska Nowa Wieś has publicly opted for limiting social security payments for the Romas. The representatives of European organizaionts of national minorieties and defenders of human rights strongly criticised that public apeal (UNHCR, 1998; Żarna, 2015, p. 139). A distinct policy pertaining to national minorities and ethnical groups was implemented by Michał Kovac, who assured Hungarian minorieties about his willing to protect them from public discrimination (Orlof, 2013, p. 257).

On $4^{\text {th }}$ October 1993 in Luxemburg, Mečiar signed an association agreement between Slovakia and the EC and their member countries. The agreement came into force on $1^{\text {st }}$ February 1995 (Europska dohoda, 1997).

\section{Mečiarism}

After the elections in Autumn 1994 and coming to power of Movement for a Democratic Slovakia (HZDS) - The Slovak National Party - (SNS) The Union of the Workers of Slovakia, a number of incidents complicated mutual relations between the EU and Slovakia. After the events from the night of the $3^{\text {rd }}-4^{\text {th }}$ of November, when the coalition MP's pushed through a numer of personal decisions regarding the main posts in the country, there was a strong disaproval from the EU. On $24^{\text {th }}$ November, the ambassadors of Germany and France handed Michał Kovac a protest demarche prepared during the EU foreign affairs ministers' meeting on $22^{\text {nd }}$ November. The document underlines that EU was strongly concerned about some aspects of political life following the parliamentary elections. Moreover, the Union expressed the expectiation that the Slovak Republic would continue introducing the reforms. Heike Zenker, the German ambasador said that the EU is an organization that respects cetrain rules of the political game, and whoever wants to join it has to respect and follow them (Delong, Żarna, 2013, p. 16).

German leadership in the EU started in the second half of the 1994. The policy paper, which included all the objectives of the presidency, considered strengthening relations with the candidate countries and suporting their efforts in gaining accession 
to the EU. The Union focused on intensifying the political dialogue and reforming the PHARE programme. In August, Klaus Kinkel, the German minister of foreign affairs, in his speech made in front of German Association of Foreign Policy noted that Germany has tremendous responsibilities before them, and the main European task is to strenghten and expand European integration. These were the priorities for German foreign policy (Zięba, 2010, pp. 66-67). Towards the end of the German presidency, a European Council meeting was organised in Essen on 9-10 ${ }^{\text {th }}$ December 1994, where the document containing the strategies of preparing for EU admission of Central European countries was prepared. The Union pointed to the neccessity of introducing measures that would move these countries towards the European market. There was a discussion concerning the following questions; incorporating the candidate countries within the Common Foreign and Security Policy; enhancement of the transport and communication network; matters of education and culture. The Union announced that they would hold regular consultations between heads of states and goernments and the ministers of particular resorts (Góralczyk, 1999, p. 16; Łastawski, 2006, p. 272).

At the beginning of the 1995, the Presidency of the European Union was taken over by France. At the EU summit in Cannes on 26-27 June 1995, the Union accepted The White Paper formely prepared and elaborated by the European Commission, concerning preparation of the associate countries for integration with the internal EU market. The White Paper obliged the candidate countries to intensify the measures to adjust their economy and legislation to European standards. Jacek Wojnicki describes it as the first step towards including the countries of Central Europe into the process of establishing the four freedoms: migration of people, goods, serices and the capital (Wojnicki, 2006, p. 155). On the second day of the summit, V. Mečiar tabled a second, official aplication for Slovak membership to the European Union. On $4^{\text {th }}$ February Slovakia adopted a document $A$ National programme of adjusting Sloak legal regulations to those of the Union, the so called "Slovak White Paper" (Durica, 1996, p. 265).

The European Council summit in Amsterdam was held on 16-18 ${ }^{\text {th }}$ June 1997. The meeting was mainly devoted to the closure resolutions made in form of amendments to the Treaty of European Union, to the work of intergovernmental conference IGC), and to the questions of economic and monetary union. The outcomes of the conference were aproved during the European Council meeting in Amsterdam in 1997, and considered sufficient for negotiating the accession of the Central European countries and Cyprus. It was concluded that this was a new way to initiate the proces of enlargement of the Union. At the same time, the Union accepted the initiatiative of European Commission about introducing the aplications of the candidate countries for membership in mid July (Żarna, 2017, p. 72).

On $16^{\text {th }}$ July 1997, European Commission (EC), drawing on the recommendations of the European Council, on the establishments of IGC and on the regulations of the Amsterdam Treaty (The Treaty of Amsterdam, 1997) introduced the proposals of Agenda 2000. The Agenda included the assessments of the candidate countries and recommended to the European Council the possibility of negotiating with the six candidate countries. Slovakia was not included in the first group of countries beginning the negotiations for accession. Taking into account the political criteria, the Slovak government radically exceeded its authority towards other state organs and did not allow the oposition to control the functioning of political institutions. The EC pointed to the poor situation of citizens of the Hungarian and Roma 
minorities who were guaranteed the right to use their own language. There was a point when the European Parliament threatened to close their representation in Bratislava. The President of the EC claimed that the Slovak position with regard to national and ethnic minorities may complately block the accession of that country to the Union. The matter was significant, as the Hungarians represented $10.8 \%$ and the Romas $1.4 \%$ of the total population, and the officials were trying to impose the supermacy of one national group over all others. Moreover, Slovakia failed the second, economic criterion regarding an open market economy, however it is worth metioning that only five countries complied with this particular criteria. The third criteria concerned adapting national legislation to the European legislation. The EC claimed that Slovakia had made considerable progress regarding the implementation of the legislation within the key aspects of the unified market, however at the same time there was great concern regarding the subject. On 12-13 ${ }^{\text {th }}$ December 1997 at the summit in Luxemburg, the European Council made a final decision about the accession of some countries into the Union, excluding Sloakia (European Concil, 1997).

\section{The rule of "the blue coalition"}

The ensuing elections in Slovakia arouse emotions and, in context of accession, the event was treated almost like a referendum. Politicians, experts and European clerks came to the conclusion that it was not about who would be in power, but how would the situation change within those areas where Sloakia failed to meet the requirements of the Union. What is more, it was important to wait for the moment when the changes will be permanent. HZDS won the elecions held on $25-26^{\text {th }}$ September 1998. Despite the electoral success, Mečiar did not manage to establish a Cabinet suported by a parliamentary majority. In that case the mission of establishing the government was entrusted to Mikulaš Dziurind, the leader of the Slovak Democratic Coalition (SDK). The concerns regarding democracy in Slovakia created a situation when the representatives of European Council, EU, OSCE and even the USA had to monitor the course of elections. The observers concluded that the elections did not violate the principles of democracy (Council of Europe, 1998). The representaties of the new coalition believed that on account of former contacts, the proces of accession would go quickly and smoothly.

The first foreign visit of M. Dzurinda and Eduard Kukan, the Minister of Foreign Affairs was to the seat of the Union bodies in Brussels. On that occassion M. Dzurinda met with the President of the European Commission Jacques Santer, the President of the European parliament Jose-Maria Gil-Robles, the European Commissioner for Foreign Affairs Hans van den Brok and with the NATO Secretary General Javier Solano. Democratic changes after the elections in 1998 met with a positive response from the EU. The presidential election seemed to be cruicial, as it was the first time when the head of the state was chosen directly. Rudolf Schuster became the President of Slovakia (Bajda, 2010, p. 138-139). The success of the candidate suported by the ruling coalition eliminated the potential danger regarding the lack of cooperation between the President and the Head of Government, which was particularly noticeable during the Presidency of M. Kovać and the Prime Minister V. Mečiar, and it was the main reason for slowing down the proces of accession. 
The abovementioned changes were important because after the presidential elections the ruling organs failed for the second time, and their actions isolated Slovakia from other countries. A significant change was a draft law concerning the use of national language of the minorities and the sustainable performance of the coalition including The Party of Hungarian Coalition (SMK). Jacque Poos, the Minister of Foreign Affairs of Luxemburg claimed that the Copenhagen criteria within the area of the right of minorities have not been fulfilled. Poos was of the opinion that although the draft had already been prepared, it had yet to be passed by the Pariament and put into effect. The presence of Pál Csáky, who was responsible for the minority policy, was not a sufficient argument (Żarna, 2017, p. 82).

On $13^{\text {th }}$ October 1999 the European Commission published a report into the state of preparations of Slovakia for entering the Union. The report confirmed and elaborated on the conclusions of the Working Party. It presented positive changes that were observed in the political area. The European Comission focused in their assessment on the fact that Slovakia met the primary requirements for beginning the process of accession. Slovakia complied with the political criteria regarding democracy, legislation, human rights and freedom. The European Commission highlighted the inadequacy of Slovak courts and pointed to the lack of progress within the field of national policy. Regarding the economy, representatives of the European Commission indicated that in the light of fast-paced reforms, Slovakia apeared to be likely to meet the requirements of a funcioning market economy even by the year 2000. The competitivenes of the Sovak economy in EU depended on acceptance and implementation of the programme of legislation and structural reforms (European Commission, 1999). The report of the Comission also poitiely viewed the decision of the Sloak goernment about the closure of two plants of the V1 nuclear power station in Jaslowskie Bohunice in 2006-3008 (European Commission, 1999).

The European Council held in Helsinky on 10-11 ${ }^{\text {th }}$ December 1999 established a range of activities of the IGC in 2000 before the summit in Nice. The Council decided to start negotiations with six other candidates, the so-called Helsinky Group, including Slovakia (European Council, 1999).

The President of the European Commission, Romano Prodi, and the External Relations Commissioner Günter Verheugen, visited Slovakia in January 2000. The Union was concered whether the coalition would manage to retain control in terms of the increased costs of the reforms carried out in the state. Back in May, Verheugen was concerned about the return of Mečiar to power. The negotiation proces started on $15^{\text {th }}$ February 2000 during the inauguration of the IGC held in Brussels. The chef negotiator was Ján Figel' the Secretary of the State in the Ministry of Foreign Affairs. At the meeting both sides presented their negotiation positions. The accession process included screening - the analysis of adjusting national legislation to the EU law. In comparison to the other countries of the same region, Slovakia has negotiated very quickly and closed out some matters within 2.5 years:

- 2000; Statistics; External relations: Common foreign and security policy; Social and employment policy; small and medium-sized enterprises; Science and research; Education, training and youth; Industry policy; Culture and audiovisual policy;

- 2001: Economic and Monetary Union; Free movement of goods; Freedom of services; Company law; Telecommunication and information technologies; Customs 
Union; Free movement of people; Free movement of capital; Energy, Protection of consumers and health; Environment; Financial control;

- 2002: Taxes; Transport Policy; Agriculture; Fishery; Judical system and internal affairs; regional policy; Competition policy; Finances and budget; Institutions; Others (Figel', 2001, p. 97-102).

It is important to mention the huge determination of the Slovaks in the negotiation proces. From the country that was excluded from the the first group of the candidate countries, Slovakia has made a great step ahead becoming a leader in the negotiation proces.

The issue connected with Christian values played a vital role for many candidate countries. In Slovakia there were few euro-sceptics who claimed that joining European Union will be tantamount to legalizing abortion, euthanasia, homosexual marriages and prostitution. On $30^{\text {th }}$ January 2002, the Parliament of Slovakia accepted the independence declaration in respect to the EU in case the European law was in conflict with Christian values. The ministers reserved the right to to make separate decisions regarding three issues: protection of life and human dignity from birth until death, protection of family and the institution of marriage and in the field of health care and education. The right-wing Parties of Dziurinda's Cabinet and the representaties of the oposition L'S_HZDS of the former Prime Minister Mečiar and two National Parties voted in favour of the declaration (Grabiński, 2002, p. 11).

One of many issues that were suposed to be resolved at the Union summit in Nice was the question of how would the Union change after accession of the new countries. It was decided that in case of accepting 10 new countries, the overal number of the votes being weighted would be 345 , wherein Slovakia would get 7 . Moreover, the Union decided to increase the numer of the MP's to 732. The numer of members of the Court of Auditors and the Curt of Justice was also increased. The Slovaks were suposed to be represented in other institutions of the Union (Lastawski, 2006, p. 315).

Slovakia terminated negotiations at the meeting of the European Council in Copenhagen on $12-13^{\text {th }}$ December 2002. Anders Fogh Rasmussen, the Prime Minister of Dennmark, which was just about to finish its Presidency in the Union, took steps to finish the negotiations. The process of negotiations was rough for the candidate countries as they were trying to negotiate themselves the best possible terms. Worse terms raised doubts that the accession treaty may be rejected (Żarna, 2015, p. 94).

An interesting view onto the negotiations between Slovakia and the European Union was presented by a Slovak sociologist Michal Vašečka who claimed that in comparison to Poland, where a strong division into euro-sceptics and euro-enthusiasts could be observed, in Slovakia there was a national consensus, however he claims it was a temporary situation. While in Poland the negotiations were discussed for years, Slovakia had to follow its neighbours in negotiations. Although M. Vašečka was not concerned about the turn out at the referendum (Vaszeczka, 2003, p. 6), his optimistic views proved to be wrong.

The accession referendum was held on 16-1 $7^{\text {th }}$ May 2003 (people could vote from 2 p.m on Friday until 2 p.m on Saturday). $52.15 \%$ of all eligible citizens took part in the referendum. On the fist day of voting the turn out slightly exceeded $25 \%$, so the major Slovak politicians including the President Rudolf Schuster and the President of the Parliament Pavol Hruszovský apealed the citizens of Slovakia to take part in the referendum. The Slovaks responded to the following question: Do you agree for Slovakia to become 
member of the European Union? $92.46 \%$ of voters were for and 6.2\% were against. The results of the referendum were valid, as according to the rules of the law $50 \%$ of people entitled to vote took part in the referendum. Many young people who lived in Petrżalka, the largest part of Bratislava hurried to vote in the last thirty minutes of the referendum. Eventually, Slovakia accessed the Union thanks to the inhabitants of the largest cities like Bratislava or Košice where over $60 \%$ of people voted. That was enough to compensate a low turn out in other smaller cities and towns for example in Kraj Żyliński. The highest turn out was observed in three areas of Bratislava, while the lowest - 36.8\% in Czadca situated on the border with Poland. In two (out of 8) voivodships and in 30 (out of 79) counties turn out was lower than 50\% (Grabiński, 2003, p. 10).

An agreement regarding the accession to the EU was reached among the ruling party and the oposition. A similar position was represented by the government and the President. The Communist Party and euro-sceptic Institute of Republicans were against the accession. Radosław Zenderowski divided Slovak political parties in the context of European integration into two cathegories. The first cathegory is socalled slight euro-sceptism and was represented by the Communist Party (KSS) and Slovak National Party (SNS) (which demonstrated features of tough euro-sceptism) and the Christian Democratic Movement (KDH). Members of this cathegory were not oposed to the membership of Slovakia and its European integration, however in some matters they showed their disaproval for EU or enhanced discrepancies between the national interest and the current model of European integration. What is more, they called for reforms. The second cathegory is functional europeism represented by Smer, Hzds, SMK, Alliance of the New Citizen (ANO), Slovak Democratic and Christian Union - Democratic Party (SDKÚ-DS.) who expressed a tendency for "identity europeism." Those who belonged to that cathegory were of the opinion that suportting European integration promotes the implementation of national interests and the aims of particular political parties. The call for a national status quo took precedence over the proces of European integration. "Tough euro-sceptism" was strongly oposed to the European Union and insisted on either leaving the Union or on a complete change in the trajectory of European integration. On the other hand, "the identity europeism" seemed to be in complete oposition. It indicateed suport for European integration; suported the change from national into European competences; suported the European political system and strengthening a sense of European citizenship (Zenderowski, 2007, p. 288).

The Treaty of Accession was signed together with the other nine countries on the 16th of April 2003 in Athens (The Treaty of Accession, 2003). The day after signing the treaty, the candidate countries gained the status of an active observer, which allowed participation in the meetings of all the EU bodies, presentation of their viewpoints, however they they could not yet make any formal decisions. The Slovak government ratified the Treaty on $1^{\text {st }}$ July 2003 by a clear majority of votes; 129 to 10 . The representatives of KSS were oposed to that decision. On $26^{\text {th }}$ August 2003, Schuster officially signed the Treaty of Accession. The Prime Minister, Mikuláš Dzurinda, the President of the Parliament Pavol Hruszovský, and representative of European Commision Eric van der Linden were also present at the ceremony of signing (Gábelová, Gajdzica, Mesežnikov, 2003, pp. 786-789). 
On $1^{\text {st }}$ May 2004 ten new countries joined the European Union: Cyprus, Czech Republic, Estonia, Lithuania, Latvia, Malta, Poland, Slovakia, Slovenia and Hungary.

The elections for the European Parliament were held in July 2004. It was a fist public test for the populatity of the Union and the idea of integrity among the ten new countries. It had a rather negative outcome in terms of turn out. In the new countries the frequency was $20 \%$ lower than in the Member States of the EU-15 (26\% to $47.8 \%$ ). The reason was not only the "democracy deficit," but also the fact that people became tired of the internal political life. The voting confirmed tendencies visible throughout the wole Union; the best results were among conservative parties, right-wing, populist and anti-european parties. The oposition groups seemed to get more suport than the government ones. Slovakia was noted with the lowest turn out of $16.96 \%$ (Bilčík, 2004, pp. 445-447). There were a few reasons for it. The previous elections were held not long before: in Autumn 2002 Parliamentary elections, in May 2003 a referendum and in April 2004 Presidential elections. It caused a sort of reluctance among voters. What is more, socjety was certain that "not much work hapens in the European Parliament." The political parties did not make an effort to organise big election campaigns. In the European Parliament, Slovakia is represented by fourteen reopresentatives: The European People's Party group and the European Democrats -8 MEPs, the Socialist Group - 3 MEPs, the non-attached Members - 3 MEPs (Żarna, 2017, p. 110-111).

Taking into account the European Commission and in accordance with the establishments set out in Nice, the Union introduced a policy: one country and one commissioner. The Christian Democratic Movement suggested Ján Figel' for the post. He performed the fucntion of the Commissioner for Enterprises and Information from $1^{\text {st }}$ May 2004. The Presidency of Romano Prodi in the Commission was about to finish in October 2004. The next President was a Portuguese; Jose Manuel Baroso. Ján Figel' became the European Commissioner for Education, Training and Culture. The scandal around Rocco Buttiglione, who was a candidate for the post of Commissioner, did not allow the Commission to start its work from $1^{\text {st }}$ November 2004. J. M. Barroso steped down under pressure from both parliament and public opinion, and Buttinglione replaced Franco Frattini. Ján Figel' officially started to perform his function on $22^{\text {nd }}$ November 2004 (Bilč́́k, 2004, pp. 447-448).

\section{Final remarks}

Under the rule of Vladimír Mečiar Slovakia was internationally isolated. It had rather bad relations with the countries of Western Europe, United States and other neighbours. Slovakia was not considered to be a part of the proces of accession at the summit in Madrid 1997 because it did not meet the membership requirements within the euroatlantic structures. In 1998 the other countries of Vysehrad Group: Poland, Czech Republic and Hungary joined NATO. In 1997 Slovakia failed again in the international arena. At the summit in Luxemburg six countries were invited for negotiations: Czech Repubic, Cyprus, Estonia, Poland, Slovenia and Hungary. Slovakia was included in the so called "Helsinki group" and in 1999 it started its negotiation proces. The vital moment was the deselection of Vladimír Mečiar who was replaced by Dzi- 
urinda. Since then, joining the Union became the priority for the new government. In 2000 Sloakia intensified its negotiation process with the European Commission forging ahead of other candidate countries from the "Luxemburg group" in the numer of fulfilled requirements. Slovakia became a country which attracted many foreign investors. Because of the strong economic growth, Slovakia gained the nickname of "The Tiger of the Central Europe." Changes in the political system and economy also had some bad effects which included a high rate of unemployment and problems connected with social policy, like significant expenses for social benefits of the Roma minorities. The Union referendum became a manifesto to suport Slovak society in the European integration. The only point of concern regarded the trun out that sightly exteeded the required $50 \%$. Representatives of almost all of the political parties were enthusiastic about such a situation, the only doubts were of a more global nature.

\section{Bibliography}

Bajda P. (2010), Elity polityczne na Stowacji w latach 1989-2010. Kręta droga do nowoczesnego państwa, Warszawa.

Bilčík V. (2004), Slovensko a Európska únia, in: Slovensko 2004. Súhrnná správa obecnych stave spoločnosti, eds. M. Kollár, G. Mesežnikov, Bratislava.

Council of Europe (1998), Observation of parliamentary elections in Slovakia (25-26 September 1998), http://assembly.coe.int/Main.asp?link=/Documents/WorkingDocs/Doc98/ EDOC8254.htm, 10.12.2016.

Delong M., Żarna K. (2013), Republika Stowacka i Rzeczpospolita Polska na drodze do Unii Europejskiej, Rzeszów.

Durica M. S. (1996), Dejiny Slovenska a Slovakov, Bratislava.

European Comission (1999), Composite paper. Reports on progress towards accession by each of the candidate countries, 13.10.1998, http://ec.europa.eu/enlargement/archives/pdf/key_ documents/1998/composite_en.pdf, 12.03.2018.

European Council (1993), Copenhagen criteria https://eur-lex.europa.eu/summary/glossary/accession_criteria_copenhague.html, 22.03.2018.

European Council (1997), Luxembourg European Council, 12 and 13 December 1997. Presidency conclusions, http://www.europarl.europa.eu/summits/lux1_en.htm, 28.03.2018.

European Council (1999), Helsinki European Council 10 and 11 December 1999. Presidency conclusions, http://www.europarl.europa.eu/summits/hel1_en.htm, 31.03.2018.

Európska dohoda o pridruženi uzatvorená medzi Európskymi spoločenstvami a ich členskými štátmi na strane jednej a Slovenskou republikou na strane druhej, Z.z. 158/1997.

Figel' J. (2001), Slovenská republika a Európska únia, in: Ročenka zahraničnej politiky Slovenskej republiky 2000, ed. A. Kotvanová, Bratislava.

Gábelová B., Gajdzica M., Mesežnikov G. (2003), Kronika udalostí (1. decembra 2002-30. novembra 2003), in: Slovensko 2003. Súhrnná správa o stave spoločnosti, eds. M. Kollár, G. Mesežnikov, Bratislava.

Góralczyk B. (1999), Rozszerzenie Unii Europejskiej na Wschód: początek budowy „ładu brukselskiego" w Europie, in: Rozszerzenie Unii Europejskiej na Wschód. Dokumentacja akcesyjna, t. 4, ed. B. Góralczyk, Warszawa.

Grabiński T. (1993), Ulga i sukces, „Gazeta Wyborcza” z 19 V.

Hartnell H. E. (1993), Association Agreements between the EC and Central and Eastern European States, “Acta Juridica Hungarica,” no. 35, pp. 225-236. 
Łastawski K. (2006), Historia integracji europejskiej, Toruń.

Ružička F. (2009), Droga Stowacji do członkostwa w Unii Europejskiej, in: Negocjowanie granic: od ,UE-15” do ,UE-27”. Rozszerzenie wschodnie Unii Europejskiej. Część druga - 'Grupa helsińska' (2004-2007) Litwa, Łotwa, Stowacja, Malta, Butgaria, Rumunia w UE, ed. T. R. Szymczyński, Poznań.

The Treaty of Accession of the Czech Republic, Estonia, Cyprus, Latvia, Lithuania, Hungary, Malta, Poland, Slovenia and Slovakia (2003), https://eur-lex.europa.eu/collection/eu-law/treaties/ treaties-accession.html\#new-2-30, 28.03.2018.

UNHCR, Guidelines Relating to the Eligibility of Slovak Roma Asylum Seekers, 10 II 1998, http:// www.unhcr.org/refworld/category,POLICY,,SVK,3ae6b31c54,0.html\#_ftn41, 20.07.2017.

Wojnicki J. (2006), Instrumenty rozszerzenia Unii Europejskiej o państwa Europy Środkowej (Czechy, Polska, Stowacja, Słowenia, Wegry), in: Dialog europejski Zachód-Wschód. Polityka - gospodarka - społeczeństwo, eds. A. Stępień-Kuczyńska, T. Jałmużna, Torun.

Zenderowski R. (2007), Nad Tatrami błyska się... Stowacka tożsamość narodowa w dyskursie politycznym w Republice Stowackiej (1989-2004), Warszawa.

Zięba R. (2010), Główne kierunki polityki zagranicznej Polski po zimnej wojnie, Warszawa.

Żarna K. (2015), Od Mečiara do Dzurindy. Główne kierunki polityki zagranicznej Republiki Stowackiej w latach 1993-2002, Wydawnictwo Uniwersytetu Rzeszowskiego, Rzeszów.

Żarna K. (2017), Republika Słowacka na drodze do Unii Europejskiej i Sojuszu Pólnocnoatlantyckiego, Wydawnictwo Państwowej Wyższej Szkole Zawodowej im. Rtm. W. Pileckiego, Oświęcim.

\section{Summary}

The article is based on the assumption that the politics of Vladimir Mečiar, in particular human rights breaches, negatively inluenced the process of Slovakia's accession to the European Union. Another hypothesis is that in comparison to other countries of Central Europe, Slovak political parties reached a national consensus concerning accession to the European Union.

Key words: European Union, human rights, Slovakia, Vladimír Mečiar, Mikulaš Dzurinda

\section{Przystąpienie Słowacji do Unii Europejskiej}

\section{Streszczenie}

Niniejszy artykuł opiera się na założeniu, że polityka rządu Vladimira Mečiara, w szczególności liczne przypadki naruszeń praw człowieka, negatywnie wpłynęła na proces przystąpienia Republiki Słowackiej do Unii Europejskiej. W porównaniu z innymi państwami regionu Europy Środkowej, w przypadku słowackich partii politycznych osiągnęły one narodowy konsensus dotyczący przystąpienia do Unii Europejskiej.

Słowa kluczowe: Unia Europejska, prawa człowieka, Słowacja, Vladimír Mečiar, Mikulaš Dzurinda 